\title{
Pemberdayaan Masyarakat Dalam Meningkatkan Kepedulian Lingkungan Berbasis Potensi Lokal
}

\author{
Harianto \\ ${ }^{2}$ Fakultas Ilmu Sosial dan Ilmu Politik, Universitas Merdeka Madiun, Jl. Serayu No.79, Madiun, 63133 \\ E-mail: harianto@unmer-madiun.ac.id
}

\begin{abstract}
In the village of Keras Kulon, Gerih Subdistrict, Ngawi Regency most of the people are farmers. That way most of it is used for processing agricultural land. On the other side of the house, each farmer's family and other families have many courtyards and yards that are quite large and not well-maintained with lots of overgrown plants which originate from planting and as long as they grow by themselves. Therefore, there is still a gap to empower the community, especially for women farmers and female families who are members of the PKK by utilizing existing land in each in the yard or in the yard by cultivating Ginger plants. Ginger cultivation has strategic values both economic and non-economic for the community to provide added value both economically and non-economically as well. Ginger plant cultivation that can easily be done by PKK members on their spare time so that the land in the yard or in the yard of the house will be planted with ginger plants planted on the sidelines and mango plants, jackfruit trees, banana trees and so on. Empowering rural communities through PKK, considering the most active organization in the village for mothers is PKK. This empowerment is to improve environmental awareness based on local potential, and plants according to needs. The community service activities will be held from September to December 2018. At regular PKK meetings scheduled every month in Keras Kulon Village, Gerih District, Ngawi Regency as a community with assistance and assistance methods.
\end{abstract}

Keywords - : Community Empowerment; Environmental Awareness; Local Potential.

\section{PENDAHULUAN}

Pemberdayaan masyarakat utamanya pada keperdulian lingkungan berbasis potensi local saat sekarang ini sedang dikembangkan. Hal ini penting dalam rangka mewujudkan ketahanan pangan dan peningkatan pendapatan masyarakat dan mengurangi kemiskinan.

Salah satu kabupaten yang berada di lingkup Propinsi Jawa Timur adalah Kabupaten Ngawi, di bawah naungan Kabupaten Ngawi adalah Kecamatan Gerih, utamanya Desa Keras Kulon tempat atau lokasi pengabdian pada masyarakat ini dilakukan.

Desa Keras Kulon Kecamatan Gerih Kabupaten Ngawi tersebut kurang memiliki keperdulian lingkungan yang berbasis pada potensi local, dimana masih banyak lahan kosong sekitar rumah baik yang berada di halaman rumah, samping rumah maupun di pekarangan rumah. Tanaman yang tumbuh di tempat-tempat tersebut terlihat sebagian besar asal tanaman itu tumbuh dan tidak terpeliharan dengan baik. Hal tersebut terjadi karena sebagian besar masyarakat Desa Keras Kulon Kecamatan Gerih adalah bertani. Sepanjang waktunya habis digunakan untuk penggarapan lahan pertanian utamanya tanaman Padi. Sedang para wanita tani dan ibu-ibu yang lain setelah kegiatan utamanya selesai banyak yang tidak memanfaatkan waktu luangnya pada kegiatan-kegiatan yang produktif.

Banyak organisasi-organisasi di Desa Keras Kulon Kecamatan Gerih, tetapi yang aktif dan hidup berkegiatan secara terjadwal dan kontinyu berlanjut adalah PKK desa. Mengingat organisasi ini memang diperuntukan bagi kaum perempuan di desa dalam rangka pemberdayaan keluarga dan kegiatan operasionalnya telah teranggarkan dalam Anggaran Pendapatan Belanja Desa (APBDes) pada setiap tahunnya dibandingkan organisasi-organisasi atau paguyuban-paguyuban lain. Melaui PKK inilah pemberdayaan masyarakat melalui keperdulian lingkungan berbasis potensi local dilaksanakan.

Masalah masyarakat di Desa Keras Kulon Kecamatan Gerih Kabupaten Ngawi adalah kurangnya kesadaran masyarakat, terlebih tentang keperdulian lingkungan.

Banyak tempat-tempat terbengkalai kebersihannya karena minimnya kemampuan, pemahaman dan keinginan masyarakat untuk perduli serta untuk meningkatkan pendapatan ekonominya. Hal ini penting, dalam rangka sosialisasi kesadaran masyarakat akan pentingnya keperdulian lingkungan dalam pemanfaatan lahan kosong serta hasilnya dapat meningkatkan ekonomi keluarga. Selain permasalahan di atas, maindset masyarakat dalam menyambut keperdulian lingkungan melalui potensi lokal. Konsep pemberdayaan masyarat menuju masyarakat sadar lingkungan tentunya dikelola secara koordinatif dan terpadu dengan prinsip transparantif, partisipatif, dan akuntabilitas serta mencerminkan nilai-nilai sosial budaya yang ada dan berkembang di masyarakat berbasis potensi lokal. Sehingga kemajuan desa untuk mengembangkan keperdulian lingkungan berjalan dengan seimbang antara kearifan lokal Desa Keras Kulon Kecamatan Gerih Kabupaten Ngawi. 


\section{METODE PELAKSANAAN}

Kegiatan pengabdian kepada masyarakat ini direncanakan dilaksanakan pada bulan September sampai bulan Desember 2018, dengan sasaran sebagai peserta program pemberdayaan adalah ibu-ibu yang tergabung dalam PKK Desa Keras Kulon Kecamatan Gerih Kabupaten Ngawi. Kegiatan pengabdian ini dilakukan dengan pola "pendampingan" sebab, pada prinsipnya pendampingan merupakan upaya untuk menyertakan masyarakat dalam mengembangkan berbagai potensi sehingga mampu mencapai kualitas kehidupan yang lebih baik serta dengan prinsip "partisipasi", yaitu program (keperdulian lingkungan berbasis potensi local, yaitu dengan memanfaatkan lahan-lahan disekitar rumah dengan budidaya tanaman Jahe) yang dirasa program ini dapat menstimulasi kemandirian masyarakat dengan perencanaan, pelaksanaan dan dievaluasi.

\section{A. Perenacanaan Program}

Perencanaan peogram dilakukan dengan kelompok-kelompok PKK di Desa Keras Kulon Kecamatan Gerih Kabupaten Ngawi yang berkaitan dengan perencanaan pemberian pembekalan materi pemberdayaan masyarakat melalui budidaya tanaman Jahe dan perencanaan penanaman budidaya Jahe.

\section{B. Pelaksanaan Program}

Pada tahapan ini menyangkut tentang pelaksanaan pemberian pembekalan materi pemberdayaan masyarakat melalui budidaya tanaman Jahe dan pelaksanaan penanaman budidaya Jahe.

\section{Evaluasi Program}

Tahap ini dilakukan untuk mengevaluasi mulai dari perencanaan pemberian pembekalan materi pemberdayaan masyarakat melalui budidaya tanaman Jahe dan pelaksanaan program penanaman budidaya Jahe.

III.

\section{HASIL DAN PEMBAHASAN}

\section{A. Pelaksanaan Program}

\section{Pelaksanaan Pembekalan}

Di Desa Keras Kulon Kecamatan Gerih Kabupaten Ngawi terdapat 5(lima) kelompok PKK. Dengan kelompokkelompok tersebut melalui forum masyawarah telah disepakati, bahwa untuk pemberdayaan masyarakat melalui PKK dalam meningkatkan keperdulian lingkungan berbasis potensi local adalah budidaya tanaman Jahe. Adapun untuk budidaya tanaman Jahe tersebut disepakati pula oleh kelompok-kelompok tersebut, bahwa diperlukan pemberian pembekalan materi tentang budidaya Jahe. Adapun materi pembekalannya sebagai berikut :

\section{Budidaya Tanaman Jahe (Zingiber Officinale).}

a. Sejarah Singkat. Jahe merupakan tanaman obat berupa tumbuhan rumpun berbatang semu. Jahe berasal dari Asia Pasifik yang tersebar dari India sampai Cina. Oleh karena itu kedua bangsa ini disebut-sebut sebagai bangsa yang pertama kali memanfaatkan Jahe terutama sebagai bahan minuman, bumbu masak dan obat-obatan tradisional. Jahe termasuk dalam suku temu-temuan (Zingiberaceae), sefamili dengan temu-temuan lainnya seperti temu lawak (Curcuma xanthorrizha), temu hitam (Curcuma aeruginosa), kunyit (Curcuma domestica), kencur (Kaempferia galangal), lengkuas (Languas galangal) dan lain-lainnya. Nama daerah Jahe antara lain halia (Aceh), beeuing (Gayo) bahing (Batak), Jahe (Sunda), Jae (Jawa dan Bali), jhai (Madura), melito (Gorontalo, garaka (Ternate), dan lain sebagainya.

b. Jenis Tanaman. Jahe dibedakan menjadi 3 jenis berdasarkan ukuran, bentuk dan warna rimpangnya. Umumnya dikenal 3 varietas Jahe, yaitu :

c. Jahe putih/kuning besar atau disebut juga jahe gajah atau jahe badak. Rimpangnya lebih besar dan gemuk, ruas rimpangnya lebih menggembung dari dua varietas lainnya. Jenis jahe ini bias dikonsumsi baik saat berumur muda maupun berumur tua, baik sebagai jahe segara maupun jahe olahan.

d. Jahe putih/kuning kecil atau disebut juga jahe sunti atau jahe emprit. Ruasnya kecil, agak rata sampai agak sedikit menggembung. Jahe ini selalu dipanen setelah berumur tua. Kandungan minyak atsirinya lebih besar dari pada jahe gajah sehingga rasanya lebih pedas, disamping seratnya tinggi. Jahe ini cocok untuk ramuan obat-obatan, atau untuk ekstrak olesan dan minyak atsirinya.

e. Jahe merah. Rimpangnya berwarna merah dan lebih kecil dari pada jahe putih kecil. Sama seperti jahe kecil, jahe merah selalu di[panen setelah tua dan juga memiliki kandungan minyak atsiri yang sma dengan jahe kecil sehingga cocok untuk ramuan obat-obatan.

f. Keistimewaan Jahe. Diantaranya : sangat dibutuhkan sebagai bahan baku obat tradisional/jamu, kebutuhan akan jahe cenderung meningkat rata-rata 5000 ton/tahun untuk industry obat tradisional, kebutuhan pabrik jamu sido muncul 15 ton/bulan sedangkan air mancur 15 ton/bulan, temu kencono $10-12$ ton/bulan, indotraco 40 ton/bulan, pasokan jahe oleh petani ke pabrik 310 ton/tahun, permintaan jahe gajah untuk Negara Belanda 40 ton/bulan tidak terpenuhi, harga/kg rata-rata $\mathrm{Rp} 5.000-\mathrm{Rp} 6.000, \mathrm{~B} / \mathrm{C}: 3,50$. 
Website : http://dayamas.unmermadiun.ac.id/index.php/dayamas

g. Syarat Tumbuh. Tumbuh dengan baik di daerah tropis, pada ketinggian 0-1.700 m dpl, tumbuh optimum $200-600$ $\mathrm{m} \mathrm{dpl}$, curah hujan $2.500-4.00 \mathrm{~mm}$, suhu sedang panas, memerlukan sinar matahari yang banyak (> 8 jam), tumbuh pada tanah yang subur, gembur, banyak bahan organic atau humus, $\mathrm{pH}$ tanah $6,8-7,0$, jenis tanah andosol, latosol merah coklat terutama pada lahan hutan yang baru dibuka.

h. Penyiapan Benih. Tanaman jahe diperbanyak secara vegetative dengan persyaratan : tanaman berasal dari induk yang sehat, cukup tua dan dipanen pada umur 10 - 12 bulan, rumpun induk pertumbuhannya normal, kekar dan tidak terserang penyakit, penampakan secara rimpang secara visual mulus tidak busuk mengkilat bebas dari hama penyakit, rimpang telah mengalami penyimpanan (ditunaskan) selama $1-1,5$ bulan, rimpang siap ditanam jika sudah bertunas sepanjang $2-3 \mathrm{~cm}$.

i. Penunasan Rimpang. Rimpang jahe yang baru dipanaen dijemur sementara (tidak sampai kering) kemudia disimpan sekitar 1 - 1,5 bulan, rimpang yang dipatah-patahkan dengan tangan atau pisau yang steril, setiap potongan memiliki 3 - 5 mata tunas kemudia dijemur 5 atau sampai 8 jam, buat larutan bahan kimia dari agrimicin dan ZPT yang dilarutkan dalam air dengan dosis 30 gram agricimin, $25 \mathrm{ml}$ ZPT dan air 100 liter, celupkan benih yang telah dijemur tadi ke dalam larutan tersebut kemudian tiriskan dan jemur kembali kemudian masukkan ke dalam peti kayu, letakkan benih dalam peti kayu bagian bawah lapisi dengan abu gosok atau sekam padi letakkan benih pada masingmasing satu lapis benih taburi abu gosok atau sekam sehingga pada lapisan atas abu gosok atau sekam, setelah $2-4$ minggu benih jahe telah berkecambah.

j. Persiapan Lahan. Olah lahan dua kali, yaitu olahan kasar dan halus. Cangkul sedalam 25 - $35 \mathrm{~cm}$ dan biarkan selama satu minggu, lakukan pengolahan tanah sampai benar-benar gembur, buat bedengan dengan ukuran 60 - 120 cm dan tinggi $25-30 \mathrm{~cm}$ panjang bedengan disesuaikan dengan luas lahan.

k. Penanaman. Lakukan penanaman pada awal musim penghujan, Buat lubang tanam sedalam $25 \mathrm{~cm}$ dengan diameter $25 \mathrm{~cm}$ dengan jarak antar lubang pada bedengan $30-60 \mathrm{~cm}$, taburkan pupuk kandang $1 \mathrm{~kg} / \mathrm{lubang}$ tanam urea/ZA 5 - 10 gram/lubang tanam, biarkan selama seminggu, tutup lubang tanam dengan tanah kemudia tanam bibit tersebut dengan mata tunas mengarah ke atas dan usahakan bibit tidak menyentuh pupuk jandang/pupuk buatan, letakkan bibit pada lubang tanam dengan posisi rebah dan setiap lubang tanam hanya untuk satu bibit.

1. Pemeliharaan. Lakukan penyulaman pada tanaman mati atau tunas tidak tumbuh, lakukan penyiangan dan pembumbunan setelah tanaman berumur $2-4$ minggu, lakukan pemupukan susulan pada umur $6-8$ minggu setelah tanam (TSP dan KCL dengan dosisi masing-masinbg $125 \mathrm{kh} / \mathrm{ha}$ )., lakukan pengamatan rutin dan kendalian hama dan penyakit (secara kimia dan mekanis).

m. Pengendalian Hama Dan Penyakit. Penyakit layu bakteri (Pseudomonas solanacearum) gejala dengan serangan daun-daun yang ada di bawah menguning daun melipat akhirnya layu dengan cepat dan menyebar ke pucuk cara penanggulangannya tidak menanam jahe di areal terserang selama $3-5$ tahun, penyakit busuk rimpang (Fusarium oxysporum) tumbuh dengan baik pada suhu 20 - 25 derajat Celsius gejala serangan terjadi perubahan warna pada daun dari hijau tua menjadi kuning dan berangsur-angsur menjadi layu, bercak daun (Phyllosticta zingiberi) daun terlihat bintik-bintik berwarna kuning daun lambat laun menjadi berlubang pengendaliannya dengan sanitasi.

n. Panen. Pemanenan tanaman jahe pada umur $10-12$ bulan setelah tanam, alat pemanenan gunakan garpu atau cangkul dan hati hati rimpang jangan sampai rusak, bongkar rimpang jahe kemudian angkat angkat secara perlahan, berishkan rimpang jahe yang telah dipanen kemudian masukkan ke dalam kernjang bamboo atau kotak kayu yang mempunyai rongga udara.

o. Pasca Panen. Tahapan pengolah jahe meiputi penyortiran, pencucian, pengirisan, pengeringan, pengemasan dan penyimpanan. Setelah panen, rimpang harus secepatnya dibersihkan untuk menghindari kotoran yang berlebihan serta mikroorganisme yang tidak diinginkan. Setelah pencucian, rimpang diangin anginkan untuk mengeringkan air cucian. Untuk penjualan segar, jahe dapat langsung dikemas. Tetapi bila diinginkan dalam bentuk kering maka perlu dilakukan pengirisan rimpang setebal $1-4 \mathrm{~mm}$. Rimpang kering dapat dikemas dalam peti, karung atau plastic yang kedap udara dan dapat disimpan dengan aman apabila kadar airnya rendah.

\section{B. Penanaman Budidaya Jahe}

Setelah kelompok-kelompok PKK tersebut mendapatkan pembekalan terkait dengan budidaya tanaman Jahe, maka pada berikutnya adalah pelaksanaan penanaman budidaya tanaman Jahe. Dalam hal ini setiap kelompok dengan musyawarah menentukan salah satu anggota kelompok yang mempunyai lahan pekarangan yang cukup luas untuk dijadikan lokasi penanaman budidaya Jahe. Penyiapan lahan dan penanaman Jahe dilakukan bersama sama.

Dalam tahap pelaksanaan program budidaya tanaman Jahe ini, pendampingan dilakukan pada lima kelompok PKK yang ada di Desa Keras Kulon Kecamatan Gerih Kabupaten Ngawi.

\section{Evaluasi Program}

Pada tahap evaluasi program pemberdayaan masyarakat untuk meningkatkan keperdulian lingkungan yang berbasis local, yaitu budidaya tanaman jahe di Desa Keras Kulon Kecamatan Gerih Kabupaten Ngawi telah didapati, antara lain :

1. Pada pelaksanaan pemberian pembekalan materi pemberdayaan kepada kelompok-kelompok PKK dirasakan kurang maksimal. Hal ini dikarenakan keadaan 4 tempat pembekalan ada di rumah salah satu anggota kelompok PKK. 
Website : http://dayamas.unmermadiun.ac.id/index.php/dayamas

2. Pada pelaksanaan pendampingan penanaman budidaya tanaman Jahe dirasakan juga kurang maksimal. Hal ini disebabkan keterbatasan tenaga, waktu dan biaya.

\section{IV.KESIMPULAN}

Hasil dari kegiatan pengabdian kepada masyarakat di Desa Keras Kulon Kecamatan Geneng Kabupaten Ngawi selama kurun waktu kurang lebih 4 bulan adalah, kesadaran masyarakat tentang keperdulian lingkungan yang berbasis potensi local utamanya budidaya tanaman Jahe telah tumbuh. Masyarakat menyadari, bahwa selama ini lahan-lahan pekarangan yang ada disekitar rumahnya kurang termanfaatkan dengan baik dan cenderung terabaikan. Dengan tumbuhnya kesadaran ini harapannya adalah sudah tidak ada lagi lahan-lahan pekarangan yang terabaikan. Semua lahan-lahan pekarangan telah termanfaat dengan budidaya tanaman-tanaman produktif lainnya sehingga menghasilkan nilai tambah yang berupa peningkatan pendapatan masyarakat.

\section{DAFTAR PUSTAKA}

Fahrudin, Adi. 2012. Pemberdayaan, Partisipasi dan Penguatan Kapasitas Masyarakat. Bandung: Humaniora. Najiati, Sri, dkk. 2005. Pemberdayaan Masyarakat di Lahan Gambut. Bogor: Wetlands International.

Hikmat, Harry. 2006. Strategi Pemberdayaan Masyarakat. Bandung: Humaniora.

Mardikanto, Totok, 2014, CSR (Corporate Social Responsibility)(Tanggungjawab Sosial Korporasi), Bandung, Alfabeta.

Soekanto, Soejono, 1987, Sosial Suatu Pengajaran, Jakarta, Rajawali Press.

www.bbpp-lembang.info/index.php/arsip/artikel-pertanian/518-budidaya-jahe, diakses 1 September 2018. 